\title{
Structured Physical Activity can Increase High-Density Lipoprotein Cholesterol Levels
}

Aktivitas Fisik Terstruktur dapat Meningkatkan Kadar Kolesterol Lipoprotein Densitas Tinggi

\author{
Hanna Kumari Dharaindas ${ }^{1^{*}}$, Fatimah Eliana Taufik², Amir Mahmud ${ }^{3}$, Diniwati Mukhtar ${ }^{4}$ \\ ${ }^{1}$ Faculty of Medicine, YARSI University, Jalan Letjen. Suprapto Kav.13, Cempaka Putih, Central Jakarta, Jakarta, Indonesia. \\ 2 Department of Internal Medicine, Faculty of Medicine, YARSI University, Jalan Letjen. Suprapto Kav.13, Cempaka Putih, \\ Central Jakarta, Jakarta, Indonesia. \\ ${ }^{3}$ Department of Islamic Studies, Faculty of Medicine, YARSI University, Jalan Letjen. Suprapto Kav.13, Cempaka Putih, \\ Central Jakarta, Jakarta, Indonesia. \\ ${ }^{4}$ Department of Physiology, Faculty of Medicine, YARSI University, Jalan Letjen. Suprapto Kav.13, Cempaka Putih, Central \\ Jakarta, Jakarta, Indonesia.
}

DATA OF ARTICLE:

Received: 4 Aug 2019

Reviewed: 12 Sep 2019

Revised: 23 Nov 2019

Accepted: 25 Nov 2019

*CORRESPONDENCE:

hannakumari@ymail.com

DOI:

10.18196/mm.200134

TYPE OF ARTICLE:

Research
Abstract: High levels of low-density lipoprotein (LDL) cholesterol and low levels of high-density lipoprotein (HDL) are risk factors for coronary heart disease (CHD). Early research has proven that physically active people have higher HDL levels, and it is obtained by doing regular physical exercise in both men and women. One of the exercises that have an anti-CHD effect is an aerobic exercise. This study aims to identify the effect of structured physical activity on increasing HDL cholesterol. This research is pre-experimental research with one group pretest-posttest design. Interventions given were aerobic exercise conducted at least 150 minutes per week and monitored for three months. The population and sample were members of the $\mathrm{R}$ and $\mathrm{K}$ gymnastics studio in Central Jakarta, who were 18-60 years old. Samples were selected using the purposive sampling method. Data was collected by taking the respondent's blood serum and the HDL cholesterol levels examined by enzymatic methods in the laboratory, while the data analysis used paired t-test statistical tests. The results showed an increase in HDL cholesterol levels in 18 out of 25 respondents with the results of the paired t-test $\mathrm{p}=0.001$. The conclution is structured physical activity has significant effect on increasing HDL cholesterol levels among gymnastics members.

Keywords: Aerobics; HDL cholesterol; Structured physical activity

Abstrak: Tingginya kadar kolesterol low-density lipoprotein (LDL) dan rendahnya kadar high-density lipoprotein (HDL) merupakan faktor risiko penyakit jantung koroner (PJK). Penelitian sebelumnya telah membuktikan bahwa orang yang aktif secara fisik memiliki tingkat HDL yang lebih tinggi, dan itu diperoleh dengan melakukan latihan fisik secara teratur pada pria dan wanita. Salah satu latihan yang memiliki efek anti-PJK adalah latihan aerobik. Penelitian ini bertujuan untuk mengidentifikasi pengaruh aktivitas fisik terstruktur pada peningkatan kolesterol HDL. Penelitian ini adalah penelitian praeksperimental dengan desain satu kelompok pretest-posttest. Intervensi yang diberikan adalah latihan aerobik yang dilakukan setidaknya 150 menit per minggu dan dipantau selama tiga bulan. Populasi penelitian ini yaitu anggota sanggar senam $R$ dan $K$ di Jakarta Pusat, berusia 18-60 tahun. Sampel dipilih menggunakan metode purposive sampling. Data dikumpulkan dengan mengambil serum darah responden dan kadar kolestrol HDL diperiksa dengan metode enzimatik di laboratorium. Analisis data menggunakan uji-t berpasangan. Hasil penelitian menunjukkan peningkatan kadar kolesterol HDL pada 18 dari 25 responden dengan hasil uji-t berpasangan $p=0,001$. Disimpulkan bahwa ada pengaruh aktivitas fisik terstruktur pada peningkatan kadar kolesterol HDL pada anggota senam.

Kata Kunci: Aerobik; Kolestrol HDL, Aktivitas fisik terstruktur 


\section{INTRODUCTION}

One of the cardiovascular diseases that always ranks first in Indonesia is coronary heart disease. According to the Sample Registration System survey, the mortality rate for coronary heart disease is $12.9 \%$. The results of Basic Health Research (Riskesdas) in 2013 showed that coronary heart disease is in the seventh-highest position of non-communicable diseases in Indonesia.

Significant risk factors for CHD are such as an increase in serum levels of LDL cholesterol and a lack of HDL cholesterol. ${ }^{2} \mathrm{HDL}$ cholesterol is known as good cholesterol because its high levels in the blood can reduce the risk of heart disease and stroke. ${ }^{3} \mathrm{HDL}$ cholesterol levels of $60 \mathrm{mg} / \mathrm{dL}$ or more help reduce the risk of heart disease, while HDL levels below $40 \mathrm{mg} / \mathrm{dL}$ can be a major risk factor for heart disease. ${ }^{4}$

Factors that influence the increase and decrease in HDL cholesterol levels are diet, excessive body weight, physical activity, smoking, age, gender, as well as genetics.5,6 Regular physical activity can reduce LDL cholesterol, increase HDL cholesterol, and help to lose weight. ${ }^{6}$ As women and men age, cholesterol levels increase. Before the phase of menopause, women have lower levels of total cholesterol than men. After menopause, LDL levels in women tend to rise due to a decrease in estrogen hormone. ${ }^{6}$

The recommended exercise program to improve physical fitness is CRIPE (Continuous, Rhythmical, Interval, Progressive, and Endurance) carried out continuously, rhythmically, intermittently (fast or slow), and gradually to increase freshness and cardiovascular endurance. ${ }^{7}$ Anti-CHD exercise is an aerobic exercise that aims to activate a large number of muscles continuously with a weight training that is sufficient to stimulate the lungs, heart, and blood circulation so that enough oxygen is necessary to fulfill the needs. The exercises are, for instance, gymnastics, running, swimming, rowing, jumping rope, and cycling. ${ }^{8}$ WHO (2010) ${ }^{9}$ categorizes physical activity based on age, such as 18 to 64 years old adults at least conduct a moderate physical activity such as aerobics for 150 minutes a week or substantial physical activity for 75 minutes a week.

Basic Health Research Data (2013) ${ }^{10}$ shows that Jakarta is the highest province with a population that lacks physical activity. It also becomes the factor of Jakarta to be selected in this study, especially the Cempaka Putih and Johar Baru areas as research locations. It is engaging in identifying the effect of structured physical activity on increasing HDL cholesterol levels in gymnastics members.

\section{MATERIALS AND METHOD}

This study is an experimental study with one group pretest-postest research design. The research was conducted by giving treatment in the form of structured physical activity such as aerobic exercise for a minimum of 150 minutes per week for three months (12 weeks) in one respondent group without a control group. Measurement of respondents' HDL cholesterol levels was carried out by taking blood serum at pre and post-treatment. The blood serum pre-test was taken on October 2428, 2017, and post-test on February 1-6, 2018.

The population and sample were members of the $\mathrm{R}$ and $\mathrm{K}$ gymnastics studios in Cempaka Putih and Johar Baru, who were $18-60$ years old. Samples were selected using a non-probability sampling technique, namely purposive sampling, and later 36 respondents were obtained. Inclusion criteria in this study were members of gymnastics who were 18-60 years old. Meanwhile, exclusion criteria were those who did not want to participate in this study for three months and pregnant.

Data collection was carried out by interview and observation to record the frequency of respondents 'physical activity as well as taking blood serum at the beginning and the end of the study to measure respondents' HDL cholesterol levels. The bivariate analysis in this study used a paired t-test with the Statistical Package for Social Science (SPSS) version 25 program.

\section{RESULT}

This research was conducted on two groups of female gymnastics in the R gymnastics studio in Cempaka Putih and $\mathrm{K}$ studio in Johar Baru, with a total of 36 respondents with an average BMI of $26.03 \mathrm{~kg} / \mathrm{m}^{2}$ categorized as obesity in Asian category. ${ }^{11}$ Respondents carried out structured physical activity in the form of aerobic exercise for at least 150 minutes every week for three months (12 weeks). The researchers observed the work and physical activity of the patient outside the gymnastics studio by asking the respondent directly and conducting a weekly follow-up to record the respondent's compliance. During the study, four people resigned, and seven people did not fit the inclusion criteria so that the number of samples that could be followed up for three months was 25 people. Measurements were taken twice at the beginning and the end of the twelfth week. 
Table 1. The HDL cholesterol levels-based description

\begin{tabular}{lccc}
\hline & \multicolumn{3}{c}{ HDL Cholesterol Levels $(\mathrm{mg} / \mathrm{dl})$} \\
& Min & Max & Mean \\
\cline { 2 - 4 } Pre-aerobics & 27 & 62 & 43.84 \\
Post-aerobics & 33 & 76 & 50.44 \\
\hline
\end{tabular}

Table 2. The Percentage of respondents who experience an increase and decrease in HDL cholesterol levels

\begin{tabular}{lcc}
\hline HDL cholesterol levels & Frequency & Percentage (\%) \\
\hline Increase & 18 & $72 \%$ \\
Decrease & 7 & $28 \%$ \\
\hline
\end{tabular}

Based on the result of blood sample retrieval, it showed an average HDL cholesterol level at the pre-test was $43.84 \mathrm{mg} / \mathrm{dl}$, and the posttest was $50.44 \mathrm{mg} / \mathrm{dl}$. It indicated that there is an average increase in HDL cholesterol levels by 6.6 $\mathrm{mg} / \mathrm{dl}$. The result of the statistical test using the SPSS version 25 program was $\mathrm{p}<0.05$, which indicated $\mathrm{p}=0.001$.

\section{DISCUSSION}

Based on the result of the research, it reveals that a decrease in HDL cholesterol levels occurred in 7 respondents (28\%). Meanwhile, the increase in HDL cholesterol levels occurred in 18 respondents (7.2\%). The average HDL cholesterol level before the experiment was conducted was $43.84 \mathrm{mg} / \mathrm{dl}$. Upon the three-month aerobics at the gym, there was an increase in the average HDL cholesterol level from 43.84-50.44 mg/dl. The result of the paired $T$ statistical test shows that P-value $<0.05$ is 0.001 , indicating that there is an influence of structured physical activity on increasing HDL cholesterol levels.

The interview result reveals that the respondents who experienced a decrease in HDL cholesterol levels more frequently consume foods that contain trans-unsaturated fatty acids, such as pastry, chips, fried chicken, and so on. A research report that trans-unsaturated fatty acids can increase LDL cholesterol levels and reduce HDL cholesterol levels. ${ }^{12}$

In a preliminary study conducted by Ali $(2013)^{13}$ regarding the effect of aerobic exercise on increasing HDL levels, a significant increase in HDL cholesterol levels was revealed, from $44.7 \mathrm{mg} / \mathrm{dl}$ to $48 \mathrm{mg} / \mathrm{dl}$ after aerobic exercise was conducted. Furthermore, Osanloo et al. (2012) ${ }^{14}$ in their study of the effect of combination exercises among aerobic exercise, step exercise, and endurance training on body fat percentage and lipid profile in women who were seated more frequently had elevated levels of
HDL cholesterol after 12 weeks of carrying out aerobic exercise, and step exercise.

In this case, physical activity can stimulate the activity of the lipoprotein lipase enzyme, which later catalyzes the destruction of the triglycerides in lipoproteins. There is the involvement of the lipoprotein lipase enzyme in spurring an increase in HDL cholesterol levels in the blood after physical activity. In this case, it can be concluded that longterm endurance or aerobic activity causes an increase in lipoprotein lipase. The product of the destruction of triglycerides later enters the blood as a precursor for the formation of HDL cholesterol. ${ }^{15}$

In terms of the limitation, the final sample size of the study did not reach the initial sample size of 30 due to the respondents' personal and medical history, and an occupation matter which went beyond the limits of the researcher's ability to prevent it. Furthermore, the researchers also did not analyze the respondents' dietary patterns and daily eating habits.

\section{CONCLUSION}

There is an effect of structured physical activity on increasing HDL cholesterol levels among gymnastics members.

\section{REFERENCES}

1. Ghani, L., Susilawati, M. D., \& Novriani, H. Faktor risiko dominan penyakit jantung koroner di Indonesia. Buletin Penelitian Kesehatan, 2016; 44(3): 153-164.

2. Stefanick, M. L., Mackey, S., Sheehan, M., Ellsworth, N., Haskell, W. L., \& Wood, P. D. Effects of diet and exercise in men and postmenopausal women with low levels of HDL cholesterol and high levels of LDL cholesterol. New England Journal of Medicine, 1998, 339 (1): 12 20.

3. Centers for Disease Control and Prevention. LDL and HDL: bad and good cholesterol. 2015. Retrieved on April, 17th 2017, from https://www.cdc.gov/cholesterol/ldl_hdl.htm.

4. National Heart, Lungs, and Blood Institute. Heart Disease Risk Factors You Can Do Something About, 2017. Retrieved on April, 19th 2017, from https://www.nhlbi.nih.gov/files/docs/resources/h eart/filipino-health manual/session-

$1 /$ moreinfo.pdf

5. Miller, M. Raising an isolated low HDL-C level: why, how, and when? Cleveland Clinic journal of medicine, 2003; 70 (6): 553-560.

6. National Heart, Lung, and Blood Institute. High blood cholesterol: what you need to know. 2001. 
Retrieved April, 20th, 2017. from https://www.nhlbi.nih.gov/files/docs/public/hear t/wyntk.pdf

7. Sinaga, R. N. Diabetes Mellitus dan Olahraga. Jurnal Ilmu Keolahragaan. 2016; 15 (2): 21-29.

8. Roza D. Pengaruh Latihan Fisik terhadap Profil Lipid Wanita Usia Dewasa. MNM, 2010; 2 (1): 29. 35.

9. World Health Organization. Global recommendations on physical activity for health. World Health Organization. 2010.

10. Balitbang Kemenkes, R. I. Riset kesehatan dasar; RISKESDAS. Jakarta: Balitbang Kemenkes RI, 2013, 110-9.

11. Douglas G, Nicol F, Robertson C. Pemeriksaan Klinis Macleod Edisi Ketigabelas. London: Elsevier. 2014.

12. Sartika, R. A. D. Pengaruh asam lemak jenuh, tidak jenuh dan asam lemak trans terhadap kesehatan. Kesmas: National Public Health Journal, 2008; 2 (4), 154-160.

13. Ali, M. A. Pengaruh Latihan Aerobik terhadap Peningkatan Kadar High Density Lipoprotein pada Atlet Aerobic Gymnastics. Media Ilmu Keolahragaan Indonesia, 2013; 3 (2), 72-77.

14. Ossanloo, P., Najar, L., \& Zafari, A. The effects of combined training (aerobic dance, step exercise, and resistance training) on body fat percents and lipid profiles in sedentary females of AL_ZAHRA University. European Journal of Experimental Biology, 2012; 2 (5), 1598-1602.

15. Rachmat, C., Ticoalu, S. H., \& Wongkar, D. Pengaruh Senam Poco-Poco terhadap Kadar Trigliserida Darah. eBiomedik, 2015; 3 (1), 205-210. 